\title{
Uncertainty Reduction Theory dalam Pola Komunikasi Pemain dan Pelatih Sepakbola Usia Dini di PFA (Pasoepati Football Academy)
}

\author{
Arif Nugrahadi \\ Universitas Muhammadiyah Surakarta \\ Email: arif.nugrahadi2@gmail.com* \\ *corresponding author
}

\section{Keywords:}

uncertainty reduction theory, interpersonal communication, players and coaches

Kata Kunci:

uncertainty reduction theory, komunikasi antarpribadi, pemain dan pelatih sepakbola usia dini.

\begin{abstract}
Communication at the beginning of the meeting is a key communication that will be a benchmark for the relationship between future interpersonal communication that will be undertaken by those who communicate. A sense of uncertainty and anxiety will arise when we do not know the information about our interlocutors who encourage us to do things that will reduce the sense of uncertainty. Inhibiting factors from inside and outside of people who communicate are very influential in the emergence of uncertainty and anxiety. Moreover, this study examines early childhood who are still in the developing stages in their environment. This study aims to determine the type of uncertainty experienced by early football players and coaches Pasoepati Football academy and how their strategies in reducing uncertainty through Charles Berger's theory of uncertainty reduction. The researcher used a qualitative descriptive method by conducting in-depth interviews with players and Paseopathic Football Academy coaches. This study shows that the uncertainty experienced by players and coaches is cognitive uncertainty, and for uncertainty reduction strategies using active, passive, and interactive strategies.
\end{abstract}

\begin{abstract}
ABSTRAK
Komunikasi pada awal pertemuan merupakan komunikasi kunci yang akan menjadi tolak ukur hubungan komunikasi antarpribadi kedepan yang akan dijalani oleh mereka yang berkomunikasi. Rasa ketidakpastian dan kecemasan akan muncul ketika kita tidak mengetahui informasi mengenai lawan bicara kita yang mendorong diri kita untuk melakukan hal yang akan mengurangi rasa ketidakpastian tersebut. Faktor penghambat dari dalam dan dari luar orang yang melakukan komunikasi sangat berpengaruh dalam munculnya ketidakpastian dan kecemasan. Terlebih lagi penelian ini meneliti tentang anak usia dini yang masih dalam tahapan berkembang dalam lingkungan mereka. Penelitian ini bertujuan untuk mengetahui jenis ketidakpastian yang dialami pemain dan pelatih sepakbola usia dini Pasoepati Football academy dan bagiamana strategi mereka dalam mengurangi ketidakpastian tersebut melalui teori pengurangan ketidakpastian dari Charles Berger. Peneliti menggunakan metode deskriptif kualitatif dengan melakukan wawancara mendalam terhadap pemain dan pelatih Paseopati Football Academy. Penelitian ini menunjukkan bahwa ketidakpastian yang dialami pemain dan pelatih adlah ketidakpastian kognitif, dan untuk strategi pengurangan ketidakpastian menggunakan strategi aktif, pasif, dan interaktif.
\end{abstract}

Copyright (C) 2019 Channel Jurnal Komunikasi. All right reserved. 


\section{PENDAHULUAN}

Sepakbola merupakan salah satu olahraga yang merupakan gabungan dari teknik individu dan tim dengan teknik dan Skill yang menyatu dalam sebuah kerjasama keseluruhan (Andrianto, 2013). Dalam sepakbola kerjasama dan komunikasi yang baik antar pemain dan juga pelatih menjadi salah satu komponen penting agar permainan dapat berjalan dengan baik sesuai dengan strategi yang diberikan pelatih karena sepakbola adalah permainan tim yang membutuhkan strategi untuk menang. Pemahaman strategi yang diberikan oleh pelatih dan penerapannya di lapangan merupakan kunci keberhasilan dalam permainan sepakbola. Komunikasi yang efektif dan efisien juga merupakan faktor keberhasilan lain dalam mewujudkan kekompakan dan kesolidan sebuah tim sepakbola.

Berelson dan Stainer berpendapat bahwa orang berkomunikasi untuk beradaptasi dengan lingkungannya, begitu juga dengan pemain dan pelatih dalam sepakbola yang menjalin hubungan baru setelah seleksi masuk tim dan menjadi satu tim yang baru. Komunikasi merupakan proses penyampaian informasi, gagasan, emosi, keahlian, dan lain-lain melalui penggunaan simbol berupa kata, tanda, gambar, dan lain-lain (Suryanto, 2015). Dalam dunia persepakbolaan komunikasi merupakan komponen penunjang yang paling penting karena menjadi jembatan antara pelatih dan pemain dalam menjalankan perintah, aba-aba, instruksi, kritik, maupun saran sehingga maksud yang ingin disampaikan oleh pelatih dapat diterima dengan baik oleh pemain.

Menurut Langgeng Jatmika yang merupakan manager dari Pasoepati Football Academy (PFA) pendidikan sepakbola usia dini bukan hanya latihan dasar-dasar dalam bemain sepakbola untuk anak-anak, melainkan juga pembinaan mental terkhusus akhlaknya. Coach Indra Sjafri juga mengatakan bahwa permainan sepakbola untuk anak-anak bukan mengarah kepada target target menjadi juara melainkan diseting untuk dapat mencintai permainan sepakbola itu sendiri, tanpa tekanan dan harus bersifat menyenangkan. Pemain usia muda masih dalam tahapan pengembangan kemampuan kognitif dimana jika pelatih tidak berhati-hati dalam menanamkan unsur kompetisi yang ketat maka diibaratkan sedang mempertaruhkan masa depan calon atlet hebat kita (Trainers, 2017).

Komunikasi antara pemain dan pelatih merupakan aspek utama dalam pembelajaran di sebuah akademi sepakbola terlebih akademi sepakbola usia dini. Menurut headcoach Pasoepati Football Academy Dwijoko komunikasi antara pemain dan pelatih itu sangatlah penting, pelatih harus tau kira kira strategi yang disampaikan bisa dengan mudah dipahami oleh pemain atau tidak dan dapat dilihat di dalam sebuah permainan. Komunikasi yang dilakukan oleh pemain dan pelatih tidaklah mudah mengingat adanya perbedaan persepsi, pengalaman, dan faktor kesenjangan usia antar pemain dan pelatih dalam akademi sepakbola Pasoepati Football Academy.

Dalam teori memperoleh kepatuhan yang dikemukakan oleh Marwell dan Schmitt kepatuhan akan diperoleh jika seseorang memiliki kekuatan untuk memberikan orang lain apa yang diinginkan. Dalam hal ini Marwell dan Schmitt mengemukakan strategi untuk membuat orang patuh yang dikelompokkan dalam lima kelmpok, yaitu imbalan, hukuman, keahlian, komitmen impersonal, dan komitmen personal (Hutagalung, 2015).

Dengan adanya beberapa faktor penghambat seperti yang dijelaskan di atas, rasa ketidakpastian menjadi salah satu hal yang paling penting dalam menghambat komunikasi antar pemain dan pelatih. Rasa ketidakpastian tersebut sering membuat seseorang kesulitan untuk menentukan apa yang harus dilakukan ketika berhadapan dengan orang yang baru dikenalnya dan tidak mengherankan jika seseorang tersebut akan berusaha untuk mengurangi rasa ketidakpastian tersebut (Sakti, 2018).

Pemain baru yang memasuki akademi sepakbola harus beradaptasi dengan lingkungan baru mereka, apalagi dengan usia yang masih dapat dikatakan sebagai anak-anak hal ini bukanlah merupakan sesuatu yang mudah. Ketidakpastian antara pelatih dan pemain serta miss communication antara keduanya sangatlah rentan terjadi yang nantinya akan menjadi penghambat keberhasilan tim tersebut, maka dari itu peranan komunikasi antarpribadi menjadi sangat penting dalam hal ini untuk mengurangi ketidakpastian dan kecemasan dalam berkomunikasi (Febriyani \& Iqbal, 2015).

Seseorang yang baru bertemu akan mengalami ketidakpastian ataupun kecemasan pada awal mereka berkomunikasi, namun ketika orang tersebut mampu mengatasi atau mengurangi ketidakpastian yang dialaminya maka hal tersebut akan sangat baik untuk pengembagan komunikasi interpersonal yang nantinya akan berdampak baik juga pada kekompakan dan permainan tim (West \& Turner, 2012).

Penelitian sebelumya yang dilakukan oleh Nurvita Wahyu Febriyanti dan Fajar Iqbal yang berjudul "Strategi Pengurangan Ketidakpastian dalam Sistem Komunikasi Interpersonal ( Studi fenomenologi pada Peserta On The Job Training Program ke Jepang dari PT. Hitachi Construction Machinery Indonesia Periode Pemberangkatan Tahun 20092012)" menjelaskan bahwa ketidakpastian yang dialami oleh peserta merupakan ketidakpastian kognitif yang disebabkan oleh dua faktor, yaitu faktor keterbatasan kemampuan dalam berbahasa dan faktor ketidaktahuan atau minimnya informasi terhadap Negara Jepang maupun karakteristik masyarakatnya (Febriyani \& Iqbal, 2015).

Penelitian lainnya dilakukan oleh Winda Primasari yang melakukan penelitian terhadap kecemasan dan ketidakpastian diri dalam berkomunikasi pada mahasiswa perantau UNISMA Bekasi. Dalam penelitian yang dilakukannya Winda memperoleh informasi bahwa semua mahasiswa perantau yang ditelitinya mengalami kecemasan dan ketidakpastian, terutama faktor perbedaan budaya yang paling kuat dalam mempengaruhi kecemasan dan kertidakpastian tersebut.Dalam 
penelitian tersebut juga dijelaskan bahwa semua orang berusaha untuk mengurangi ketidakpastian yang dialami sehingga nantinya dapat berkomunikasi dengan baik dengan mahasiswa lainnya (Primasari, 2014).

Penelitian ini lebih berfokus kepada ketidakpastian yang dialami oleh pemain dari Pasoepati Football Academy (PFA) kelahiran 2004-2005 terhadap komunikasi yang terjadi dengan pelatih mereka pada awal mereka berkomunikasi. Peneliti ingin mengetahui jenis ketidakpastian yang dialami dan bagaimana strategi yang digunakan oleh pemain dan pelatih sekolah sepakbola Pasoepati Football Academy untuk mengurangi ketidakpastian yang dihadapi saat awal berkomunikasi. Mengingat usia mereka yang masih muda, adanya kesenjangan usia dan pola berfikir atara pelatih dan pemain, serta merupakan angkatan terbaru dari sekolah sepakbola Pasoepati Football Academy sehingga akan sangat rawan sekali terjadi miss communication karena ketidakpastian yang berlangsung antara pemain dan pelatih yang mengakibatkan tidak tersampaikannya pesan dengan baik yang berdampak pada permainan tim.

\section{Komunikasi Antarpribadi}

Komunikasi antarpribadi adalah komunikasi yang terjadi antara dua orang atau lebih secara tatap muka dimana penyampai pesan dapat menyampaikan pesan secara langsung dan dapat ditanggapi secara langsung pula oleh penerima pesan (Hardjana, 2003). Deddy Mulyana juga menjelaskan bahwa komunikasi antarpribadi merupakan komunikasi yang terjadi antara dua orang secara tatap muka dimana dua orang tersebut saling melihat satu sama lain sehingga terdapat pertukaran informasi melalui verbal maupun non-verbal dengan reaksi secara langsung (Suryanto, 2015).

Dalam hal ini komunikasi yang dilakukan oleh pemain dan pelatih merupakan komunikasi antarpribadi dalam bentuk komunikasi interaksional dimana pelatih bisa menyampaikan langsung kepada pemain baik intruksi verbal maupun non verbal dan mendapat tanggapan secara langsung dari pemain. Sehingga jelas antara penyampai pesan dan penerima pesan yang nantinya akan diberikan tanggapan secara langsung.

Komunikasi antarpribadi berhubungan dengan relasi atau hubungan berikutnya, jika hubungan awal antarpribadi baik maka akan ada kemungkinan bahwa kedepannya akan terjalin relasi yang amat baik pula. Konteks komunikasi antarpribadi merupakan konteks yang luas banyak teori yang bisa mejelaskan tentang hal ini (West \& Turner, 2012).

Setiap orang membangun relasi untuk berkomunikasi, relasi dalam komunikasi interpersonal sangatlah penting karena keberhasilan komunikasi terutama untuk komunikasi jangka panjang relasi digunakan untuk menentukan kelanjutan dari komunikasi di awal pertemuan (Peranginangin \& Perbawaningsih, 2016). Dalam akademi sepakbola yang berlangsung lama relasi interpersonal dibutuhkan untuk membangun kesepakatan dan keselarasan yang baik antara pemain dan pelatih sehingga menghasilkan komunikasi yang baik yang berpengaruh pada kekompakan tim tersebut.

Komunikasi interpersonal selalu berkaitan dengan latar belakang dari individu yang berkomunikasi, tentang pengetahuan, persepsi, pengalaman, dan budaya akan mempengaruhi kualitas komunikasi yang akan terjadi (Peranginangin \& Perbawaningsih, 2016). Untuk itu diperlukan keterbukaan diri antara penyampai pesan dan penerima pesan. Menurut Johnson (1981) ada beberapa manfaat daklam keterbukaan diri, pertama keterbukaan diri merupakan pondasi yang kuat dalam hubungan komunikasi yang sehat, kedua semakin kita terbuka maka lawan bicara kita akan lebih menyukai kita sehingga akan terpancing untuk terbuka juga, ketiga orang yang rela membuka diri kepada orang lain cenderung memiliki sifat yang bahagia, keempat membuka diri merupakan jembatan untuk menjalin komunikasi yang intim denagn diri sendiri maupun dengan orang lain, kelima pembukaan diri merupakan tindakan yang realistik, tulus, jujur, dan apa adanya (Harapan \& Ahmad, 2014).

Pada awal komunikasi antarpribadi seseorang juga harus mengetahui tentang konsep diri, yang merupakan semua ide, pikiran, kepercayaan, dan pendirian yang diketahui seseorang tentang dirinya sendiri dalam berhubungan dengan orang lain sehingga nantinya akan timbul keterbukaan diri dan terjadilah komunikasi yang efektif dan intens yang menghasilkan relasi yang baik untuk penyampai pesan dan penerima pesan (Harapan \& Ahmad, 2014).

\section{Teori Pengurangan Ketidakpastian}

Dalam hidup kita selalu diselimuti dengan ketidakpastian. Melalui percakapan dan pengumpulan informasi, kita lebih bisa mengurangi ketidakpastian tersebut. Ketika kita berkomunikasi dengan orang lain kita akan cenderung untuk mengumpulkan informasi dari lawan bicara kita. Pengumpulan informasi tersebut adalah cara alamiah kita untuk nantinya memmahami lawan bicara kita sehigga nantinya kita dapat membangun sebuah hubungan yang baik dalam sebuah komunikasi (Littlejohn \& Foss, 2009). Ketidakpastian merupakan ketidakmampuan seseorang untuk memprediksi atau menjelaskan perilaku, perasaan, sikap, atau nilai-nilai orang lain. Sedangkan kecemasan merujuk pada perasaan gelisah, tegang, khawatiran atau cemas terhadap sesuatu yang akan terjadi. Teori ini menjelaskan bagaimana seseorang berkomunikasi dalam keadaan yang tidak pasti terhadap lingkungan yang mereka hadapi (Littlejohn \& Foss, 2009).

Teori pengurangan ketidakpastian mengidentifikasikan ketidakpastian dalam dua bentuk ketidakpastian yang berasal dari interaksi diadik. Pertama ketidakpastian kognitif yang mengacu pada ketidakpastian atau keragu-raguan yang dialami oleh seseorang tentang keyakinan diri mereka sendiri dan keyakinan dari orang lain. Kedua ketidakpastian perilaku dimana bentuk ini mengacu kepada masalah masalah yang diciptakan oleh individu yang diakibatkan oleh diri 
mereka sendiri dan perbuatan orang lain, yang bisa dikarenakan kurangnya informasi mengenai diri mereka sendiri dan orang lain, West dan Turner (dalam Junaedi \& Sukmono 218).

Charles Berger mengatakan bahwa pengumpulan informasi yang kita lakukan merupakan upaya dari diri kita untuk mengurangi ketidakpastian antara penyampai pesan dan penerima pesan sehingga nantinya pesan yang disampaikan akan lebih dapat diterima atau dalam kata lain terjadi komunikasi yang efektif (Littlejohn \& Foss, 2009). Berger juga mengungkapkan strategi dalam mengurangi ketidakpastian ada tiga strategi yang bisa digunakan yaitu, strategi aktif, strategi pasif dan strategi interaktif. Strategi pasif dilakukan dengan cara malakukan pengamatan, strategi aktif dilakukan dengan cara mencari informasi atau mengumpulkan informasi dengan cara apapun termasuk bertanya kepada orang lain, sedangkan strategi interaktif dilakukan dengan cara interaksi langsung dengan orang tersebut sehingga memunculkan keterbukaan diri antara keduanya (Morissan, 2018).

Teori penguranagan ketidakpastian mengungkapkan bahwa justru komunikasilah yang menjadi sebab dan akibat dari sebuah ketidakpastian karena sesungguhnya ambiguitas selalu ada didalam sebuah interaksisosial. Berger dan kolega telah mengidentifikasikan strategi yang dapat digunakan untuk mengurangi ketidakpastian. Pertama, strategi pasif dimana seseorang mengamati orang yang menjadi target dari kejauhan. Dalam hal ini mengamati reaksi target terhadap orang lain dalam situasi-situasi sosial. Kedua, strategi aktif dimana individu mengambil suatu tindakan secara langsung untuk mendapatkan informasi mengenai targetnya tetapi tidak melakukan interaksi secara langsung dengan target. Ketiga, strategi interaktif dimana individu melakukan pencarian informasi melalui interaksi langsung dengan targetnya (Budyatna, 2015).

Ketidaktahuan dalam interpersonal bukanlah sesuatu yang menyenangkan, Berger berpendapat bahwa ada dorongan lebih dari kita untuk mengurangi ketidakpastian terhadap seseorang yang baru kita kenal dengan tiga kondisi motivasi dorongan, yaitu; pertama mengantisipasi interaksi yang akan datang karena kita tahu bahwa kita akan bertemu lagi dengan orang tersebut maka itu menjadi motivasi untuk diri kita dalam mengurangi ketidakpstian. Kedua, nilai insentifitas. Kadang kita memiliki tujuan tertentu dalam berkomunikasi dengan orang lain, dalam hal ini komunikasi interpersonal yang dilakukan oleh pemain ke pelatih adalah mereka mebutuhkan ilmu dari pelatih mereka sehingga mau tidak mau mereka harus melakukan komunikasi dengan pelatih mereka dan mengurangi ketidakpastian mereka terhadap pelatih. Ketiga, penyimpangan, kadang seseorang tidak bisa kita prediksi bagaimana tindakan mereka, untuk mengurangi akan hal itu maka kita akan mencoba untuk mengurangi ketidakpastian dengan cara lebih mengetahi tentang lawan bicara kita (Griffin, 2006).

\section{METODE PENELITIAN}

Jenis metode penelitian yang digunakan dalam penelitian ini adalah deskriptif kualitaitif dengan menggunakan teori pengurangan ketidakpastian (uncertainty reduction theory). Penelitian deskriptif merupakan penelitian yang digunakan untuk menjelaskan dan menggambarkan keadaan atau fenomena yang apa adanya, penelitian deskriptif dari suatu populasi dapat meliputi kegiatan penilaian sikap atau pendapat individu, organisasi, keadaan, ataupun prosedur. Sedangkan penelitian kualitatif merupakan penelitian yang berusaha menganalisis fenomena sosial berdasarkan sudut pandang atau interpretasi individu dalam latar alamiah (Sudaryono, 2018).

Berdasarkan hal tersebut maka metode diskriptif digunakan untuk menganalisa data yang didapatkan melalui wawancara mendalam yang dilakukan langsung kepada subjek yang akan diteliti. Subjek dari penelitian ini merupakan lima pemain dari Pasoepati Football Academy kelahiran tahun 2004-2005 dan juga pelatih yang melatih anak didik kelahiran 2004-2005 karena angkatan kelahiran 2004-2005 merupakan angkatan termuda saat ini di Pasoepati Football Academy, sedangkan pelatih yang menjadi subjek adalah pelatih yang menangani tim kelahiran 2004-2005 dimana ada satu pelatih inti diantara beberapa pelatih yang melatih di Pasoepati Football Academy.

Penelitian ini menggunakan teknik purposive sampling dimana data diperoleh secara mendalam dengan sampel yang memenuhi kriteria-kriteria tertentu dari populasi yang merupakan pemain dan pelatih Pasoepati football Academy dengan tujuan memudahkan dalam meneliti. Dalam hal ini peneliti berfokus pada kepala pelatih dari sekolah sepakbola Pasoepati Football Academy (PFA) dan lima anak didik di akademi tersebut kelahiran 2004-2005. Kriteria yang ditentukan oleh peneliti adalah (a) lima orang sampel yang merupakan individu yang memiliki peran penting dalam sebuah tim sepakbola dan mempunyai kewajiban untuk berkomunikasi lebih banyak dibandingkan anggota tim yang lainnya. (b) Pemain memiliki tanggung jawab di posisi yang berbeda dalam sebuah tim tersebut. (c) Satu pelatih yang merupakan pelatih yang menangani tim kelahiran 2004-2005 dari semua pelatih yang ada di akademi sepakbola tersebut.

Penelitian ini menggunakan dua jenis data yaitu data primer dan data sekunder dimana data primer diperoleh dari hasil wawancara mendalam dengan sumber melalui percakapan secara langsung, sedangkan data sekunder diperoleh peneliti dari referensi buku, jurnal, artikel, dan website yang diperlukan dalam penelitian ini (Kriyantono, 2010).

Pengolahan dan analisis data menggunakan analisis interactive model dari Miles dan Huberman yang membagi proses analisis menjadi tiga tahapan yaitu; (1). Reduksi data dimana data dirangkum dan dipilih berdasarkan hal-hal pokok yang ingin diteliti, (2). Penyajian data yang berupa uraian yang jelas dan logis, (3). Penarikan kesimpulan dimana 
dalam tahapan ini merupakan hasil dari penelitian yang kemudian akan diuji keabsahannya. Keabsahan data akan diuji menggunakan triangulasi sumber data yang dimiliki oleh peneleti dimana peneliti mengecek ulang derajat kepercayan suatu informasi yang diperoleh dari berbagai sumber (Kriyantono, 2010).

\section{PEMBAHASAN}

Fokus dari penelitian ini adalah pengurangan ketidakpastian yang terjadi pada awal komunikasi antarpribadi yang terjadi antara pemain dan pelatih di Pasoepati Football Academy menggunakan sudut pandang dari teori pengurangan ketidakpastian oleh Charles Berger dan Richard Calebrese (1975). Dengan penggunaan teori tersebut maka peneliti akan menjelaskan konsep dan beberapa pengertian terutama yang menyangkut tentang penelitian tersebut mengenai komunikasi antarpribadi dan pengurangan ketidakpastian. Dalam penelitian ini peneliti lebih berfokus kepada ketidakpastian yang dialami oleh pemain karena pemain yang masih berusia anak-anak dalam proses berkembang membuat penelitian ini menarik untuk diteliti.

\section{A. Persepsi Diri dan Konsep Diri}

Komunikasi antarpribadi adalah komunikasi yang terjadi antara dua orang atau lebih secara tatap muka dimana penyampai pesan dapat menyampaikan pesan secara langsung dan dapa ditanggapi secara langsung pula oleh orang yang menerima pesan (Hardjana, 2003). Komunikasi antarpribadi berhubungan dengan relasi atau hubungan berikutnya setelah komunikasi awal terjadi, jika hubungan antarpribadi pada awal pertemuan baik maka akan ada kemungkinan bahwa kedepannya juga akan terjalin relasi yang baik pula melalui komunikasi antarpribadi (West \& Turner, 2012).

Untuk menjalin hubungan yang baik dalam berkomunikas seseorang harus mengetahui tentang persepsi diri dan konsep diri. Persepsi adalah proses dimana terdapat pemberian makna yang diterima oleh stimuli indrawi yang diberikan oleh rekan komunikasi kita baik verbal maupun non verbal. Persepsi berperan penting dalam keberhasilan sebuah komunikasi, sebab bila stimuli diartikan salah atau berbeda maka akan terjadi kesalahpahaman (Littlejohn \& Foss, 2009).

Persepsi yang dibawa oleh pemain pada saat awal sebelum masuk ke akademi sepakbola Pasoepati Football Academy juga bermacam-macam. Persepsi ini membuat pemain mempunyai pemikiran yang berbeda-beda dan juga mempengaruhi sikap dan pola komunikasi mereka pada awal pertemuan mereka dengan pelatih. Komunikasi interpersonal selau berkaitan dengan latar belakang individu yang berkomunikasi, tentang pengetahuan, persepsi, pengalaman, dan budaya (Peranginangin \& Perbawaningsih, 2016). Maka dari itu persepsi yang dimiliki pemain tentang akademi sepakbola dan kepada pelatihnyapun berbeda-beda. Hal ini dialami oleh kapten tim Ikhsan pada saat awal masuk ke Pasoepati Football Academy, Ikhsan mempunyai pandangan di pikirannya kalau pelatih yang akan melatihnya akan galak, hal ini dapat menyebabkan munculnya ketidakpastian dan keragu raguan dalam diri pemain untuk memulai komunikasi terhadap pelatih mereka.

Selain ketidaktahuan mengenai pelatih mereka, pemain juga minim informasi tentang klub yang akan mereka ikuti (Pasoepati Football Academy), pemain Pasoepati Football Academy pada umumnya berasal dari daerah daerah yang lumayan berjauhan, latar belakang budaya sebenarnya tidak terlalu berpengaruh dalam hal ini karena walupun agak berjauhan tetapi budaya yang mereka gunakan masih sama dengan teman yang lainnya karena masih satu karisidenan Surakarta. Rata-rata pemain yang memasuki akademi sepakbola Pasoepati Football Academy sebelumnya sudah mengikuti sekolah sepakbola di daerah masing-masing, ketika menghadapi sekolah atau lingkungan yang baru maka mereka harus beradaptasi lagi dengan lingkungan yang baru terlebih lagi usia mereka yang masih tergolong usia anak-anak.

Ketidaktahuan yang dialami oleh pemain yang lainnya adalah karena latar belakang mereka yang mengikuti akademi sebakbola karena kemauan dari orangtuanya. Mereka hanya menurut dengan orangtua mereka mau di tempat mana mereka belajar sepakbola. Hal ini membuat pemain acuh dah pasrah terhadap orangtua mereka tanpa mengetahui latar belakang dari akademi sepakbola yang akan mereka ikuti, mereka hanya tau yang penting mereka bisa bermain sepakbola.

Namun ada juga sebagian pemain yang sebelum masuk ke Pasoepati Football Academy juga mencari informasi terlebih dahulu tentang Pasoepati Football Academy melalui media sosial dan teman teman mereka yang sudah bergabung terlebih dahulu dengan Pasoepati Football Academy. Salah satunya dilakukan oleh kiper Pasoepati Football Academy yang bernama Anggit, dia memaparkan bahwa ia mencari informasi terlebih dahulu tentang Pasoepati Football Academy melaui internet dan sosial media yang dibuat oleh official klub.

Berbeda jauh dengan yang dialami oleh pelatih Pasoepati Football Academy, pelatih sama sekali tidak mengetahui bagaimana anak didik yang akan mereka latih sebab pelatih juga tidak dapat mengetahui dari mana saja anak-anak yang akan mereka latih. Pelatih hanya tahu tentang data pribadi anak didik mereka dan merupakan data yang mentah berupa nama, tinggi badan, alamat rumah, nama orangtua, dan lain sebagainya. Data tersebut diperoleh dari biodata yang dibagi oleh pelatih dan diisi oleh pemain sebelum mereka memasuki akademi sepakbola Pasoepati Football Academy.

Persepsi yang dialami oleh pemain Pasoepati Football Academi kelahiran 2004-2005 cenderung banyak yang tidak tahu mengenai klub dan juga pelatih yang akan meraka datangi. Hal ini menyebabkan kecemasan, rasa takut, dan ketidakpastian terhadap apa yang akan mereka lakukan ketika berinteraksi dengan orang-orang baru di lingkunagan yang 
baru pula. Ketidakpastian yang dialami pemain menyangkut tentang persepsi yang mereka ciptakan serta ketidaktahuan mereka tentang informasi yang seharusnya dapat mereka peroleh dari berbagai sumber, entah dari media maupun dari orang terdekat mereka. Sedangkan dari pelatih dapada dasarnya pelatih memiliki informasi mengenai pemain yang akan dididiknya namun informasi yang didapatkan juga belum cukup maksimal untuk mengetahui bagimana karakteristik pemain mereka. Dengan demikian pelatih juga harus menggali lagi informasi mengenai pemain lewat komunikasi antarpribadi yang lebih intens lagi. Ketidakpastian yang dialami oleh pemain Pasoepati Football Academy menurut teori Pengurangan ketidakpastian oleh Charles berger dan Calabrase (1975) merupakan ketidakpastian kognitif dimana mereka menciptakan sendiri ketidakpastian mereka melalui persepsi yang mereka buat sendiri sehingga mereka tidak tahu bagaimana mereka harus berperilaku dan bersikap.

Selain persepsi konsep diri juga merupakan komponen yang penting dalam komunikasi interpersonal. Konsep diri merupakan gambaran dan penilaian, pandangan dan perasaan yang kita buat sendiri mengenai diri kita sendiri. Konsep diri merupakan aspek yang berpengaruh terhadap komunikasi antarpribadi karena seseorang akan melakukan suatu tindakan berdasarkan konsep diri yang mereka bangun (Febriyani \& Iqbal, 2015). Setiap orang memiliki konsep diri yang berbeda, seperti halnya yang dimiliki oleh pemain PFA. Salah seorang pemain memiliki konsep diri dimana pemain tidak memiliki rasa kepercayaan diri yang cukup kuat pada saat mengikuti turnamen padahal pada saat latihan pemain tersebut menjalaninya dengan baik bahkan bermain bagus.

Hal ini dikarenakan pemain tersebut beranggapan bahwa dirinya merasa belum pntas untuk bermain di level tersebut bersama dengan teman temannya yang lain. Masih ada di pikiran pemain tersebut bahwa dia kurang yakin dengan kemampuannya sendiri dan belum memiliki mental bertanding yang bagus. Kurangnya rasa percaya diri tersebut menjadikan dia cemas dan takut sehingga menimbulkan ketidakpastian terhadap apa yang dia lakukan. Kejadian ini dibenarkan oleh pelatih Pasoepati Football Academy April Triyanto dalam wawancara:

... ada pemain yang pada saat latihan itu bermain bagus bahkan melebihi teman teman yang lainnya, namun pada saat pertandingan besar seperti turnamen pemain itu bingung dengan apa yang dilakukan di lapangan dan sering menggigit jarinya sebagai tanda kalau dia tidak percaya diri.

Persepsi diri dan konsep diri yang negatif tentu saja menjadi penghambat dalam sebuah komunikasi anatarpribadi dan menjadi penyebab suatu ketidakpastian yang akan berpengaruh juga terhadap komunikasi yang akan terjadi berikutnya. Kebanyakan persepsi dan konsep diri yang dimiliki oleh pemain Pasoepati Football Academy merupakan persepsi dan konsep diri yang negaif yang berasal dari diri mereka sendiri yang merupakan penyebab ketidakpastian kognitif. Seseorang tidak akan mengungkapkan perasaan dan reaksi lainnya kepada lawan bicara mereka jika mereka tidak mengenal siapa lawan bicara mereka, maka dari itu dibutuhkan keterbukaan antara penyampai pesan dan penerima pesan agar tercipta hubungan yang sehat dan relasi yang bagus antar individu (Harapan \& Ahmad, 2014). Dimana pada kasus ketidakpastian yang dialami oleh pemain Pasoepati Football Academy ini keterbukaan diri pada awal pertemuan dengan pelatih mereka sangatlah kurang sehingga terjadi sebuah ketidakpastian dalam berkomunikasi.

\section{B. Ketidakpastian dalam Komunikasi Antarpribadi}

Komunikasi antarpribadi pada dasarnya adalah komunikasi yang dilakukan oleh dua orang yang sudah mengenal maupun belum mengenal sama sekali, seberapa dekat seseorang dalam berkomunikasi pada awalnya mereka juga tidak saling mengenal atau asing. Maka dari itu mereka akan saling mencari informasi dengan melakukan komunikasi antarpribadi yang lebih mendalam (Griffin, 2006). Menurut Berger saat seseorang berkomunikasi mereka membuat suatu rencana untuk mencapai tujuan komunikasi tersebut. Semakin kita tidak pasti maka dapat dikatakan kita cenderung untuk kurang yakin dengan rencana kita tersebut sehingga tujuan yang akan dicapai tidak dapat terlaksana juga, maka dari itu orang cenderung untuk membuat rencana darurat atau alternatif lain dalam merespons rencana tersebut (Littlejohn \& Foss, 2009). Pengelolaan ketidakpastian yang baik juga akan menimbulkan relasi yang baik kedepannya antara pemain dan pelatih sehingga komunikasi yang akan terjadi akan lebih efektif.

Teori pengurangan ketidakpastian memiliki dua peran komunikasi dalam situasi antarpribadi. Yang pertama, kita mencoba untuk memprediksi dan menjelaskan komunikasi. Kedua, bagaimana komunikasi menyediakan informasi yang kita gunakan untuk menjelaskan dan memprediksi komunikasi yang akan terjadi selanjutnya. Oleh karena itu teori pengurangan ketidakpastian mengatakan bahwa komunikasi dapat menjadi sebab akibat dari ketidakpastian itu sendiri (Budyatna, 2015).

Ketidakpastian yang dialami pemain dan pelatih di Pasoepati Football Academy pada dasarnya disebabkan oleh kurangnya pengetahuan atau informasi mengenai lawan bicara mereka, ketidaktahuan tersebut menjadi penghambat dalam berkomunikasi antara keduanya. Mereka hanya megetahui rincian kasar mengenai lawan bicara mereka sehingga mereka seperti tidak tahu lagi harus membicarakan tentang apa. Seperti yang telah diuraikan sebelumnya faktor usia juga menjadi salah satu penyebab dari ketidakpastian yang dialami karena beda usia berbeda juga pengalaman dan cara berfikir seseorang. Usia yang masih tergolong usia anak anak membuat mental dan kepercayaan diri pemain belum cukup 
berkembang sehingga menimbulkan rasa takut dan cemas ketika ingin memulai komunikasi dengan pelatih. Selain itu lingkungan baru juga menjadi penyebab pemain mengalami ketidakpastian karena mereka harus beradaptasi lagi dan untuk usia mereka hal ini tidaklah mudah.

\section{Strategi Pengurangan Ketidakpastian}

Setiap orang akan mengalami ketidakpastian saat awal berkomunikasi dengan lawan bicara mereka baik yang sudah kenal maupun belum kenal, dan setiap orang yang mengalami ketidakpastian akan berusaha mengurangi ketidakpastian mereka. Pengurangan ketidakpastian akan terjadi ketika individu mempunyai motivasi untuk mengurangi ketidakpastian berdasarkan tiga parameter, yaitu; deviasi, antisipasi interaksi interaksi mendatang, dan pengendalian sumber sumber (Budyatna, 2015).

Berger dan Calabrese (dalam West \& Turner, 2012) mengatakan bahwa komunikasi merupakan alat untuk mengurangi suatu ketidakpastian, apabila ketidakpastian dapat dikurangi dengan melakukan komunikasi maka selanjutnya akan tercipta komunkasi interpersonal yang baik dan akan menimbulkan relasi yang baik juga untuk komunikasi kedepannya. Berger juga berpendapat bahwa ada tiga strategi dalam mengurangi ketidakpastian yaitu, strategi aktif, strategi pasif, dan strategi interaktif yang bermanfaat untuk mendapatkan informasi pasti mengenai orang orang yang menjadi target lawan bicaranya (West \& Turner, 2012).

1. Strategi Aktif

Strategi aktif merupakan salah satu strategi pengurangan ketidakpastian dimana seseorang melakukan sesuatu untuk mencari informasi mengenai target atau lawan bicaranya tanpa berinteraksi secara langsung dengan target yang akan menjadi lawan komunikasinya. Sebelum masuk ke Pasoepati Football Academy sebagian pemain mencari informasi mengenai Pasoepati Football Academy dan informasi mengenai pelatih mereka di media sosial dan juga mencari informasi dengan bertanya dengan pemain atau rekan mereka yang terlebih dahulu masuk ke akademi tersebut. Salah satu narasumber Anggit yang merupakan kipper dari Pasoepati Football Academy mengatakan:

\section{...Ya udah tau perkembangannya bagus, saya cari informasi lewat media. ( 08 Maret 2019)}

Usaha yang dilakukan oleh kipper Pasoepati Football Academy tersebut merupakan salah satu strategi aktif yang digunakan untuk mengurangi ketidakpastian, secara tidak langsung mengetahui informasi dari target yang akan kita ajak berkomunikasi kita jadi lebih tau tentang target tersebut dan mendapatkan topik pembicaraan sehingga tidak canggung saat berkomunikasi dengan target kita.

Strategi aktif lainnya juga dilakukan oleh kapten tim Ikhsan yang melakukan strategi aktif dengan cara bertanya kepada teman temannya yang telah mengikuti Pasoepati Football Academy terlebih dahulu. Usaha ini dilakukan agar ia mengetahui bagaimana kondisi di Pasoepati Football Academy dan bagaimana karakteristik dari pelatih yang akan melatihnya.

Sedangkan pelatih juga melakukan strategi aktif dalam mengurangi ketidakpastian yang dialaminya, pelatih melakukan pertemuan rutin dengan wali murid tiga bulan sekali. Hal ini dilakukan agar pelatih mendapatkan informasi yang lebih mendalam mengenai pemain melalui informasi yang mereka dapatkan langsung dari orangtua pemain sendiri. Dengan demikian pelatih menjadi lebih paham tentang karakteristik pemain yang lebih mendalam tanpa adanya pertemuan secara langsung dengan pemain.

Baik pemain maupun pelatih sama sama melakukan strategi aktif untuk mengurangi ketidakpastian mereka dengan mencari informasi dari berbagai sumber yang akurat sehingga kecemasan dan ketidakpastian dapat dikurangi.

\section{Strategi Pasif}

Selain mencari informasi secara aktif terhadap target yang akan diajak berkomunikasi dengan cara bertanya dan mencari informasi dari berbagai sumber pemain dan pelatih juga melakukan pengamatan terhadap target komunikasi mereka. Hal ini dilakukan agar mereka mendapat informasi yang lebih lengkap lagi dengan melakukan pengamatan secara langsng tanpa harus berkomunikasi dengan target, strategi ini dinamakan strategi pasif dalam pengurangan ketidakpastian.

Strategi pasif yang dilakukan pemain Pasoepati Football Academy adalah dengan mengamati pelatih mereka pada saat pelatih sedang melatih kelompok usia lain, dengan melakukan pengamatan secara langsung pemain akan mendapatkan gambaran secara langsung bagaimana cara pelatih mereka dalam menyampaikan strategi dan cara pelatih dalam melatih sebuah tim. Hal ini ditegaskan oleh pemain sayap Pasoepati Football Academy Alfinda yang mengatakan :

...ya saya berusaha lebih mengenal pelatih dengan cara saya melihat bagimana cara pelatih saat melatih tim lain. (11 Maret 2019) 
Sedangkan pelatih juga melakukan strategi pasif untuk megurangi ketidakpastiannya. Pelatih melakukan pengamatan terhadap pemain dalam seleksi yang dilakukan Pasoepati Football Academy sebelum masuk ke dalam tim. Dengan cara melihat dan mengamati pemain, pelatih akan mengetahui bagaimana karakterikstik pemain yang akan masuk ke Pasoepati Football Academy. Pemain dan pelatih sama sama melakukan pengamatan untuk mengurangi ketidakpastian dengan melakukan pengamatan maka mereka akan lebih tahu bagaimana mereka harus bertindak dan bersikap saat memulai komunikasi secara langsung.

\section{Strategi Interaktif}

Setelah mencari informasi dan melakukan pengamatan, pemain dan pelatih sudah memiliki gambaran terhadap target mereka dan bersiap untuk melakukan interaksi secara langsung. Interaksi secara langsung merupakan salah satu bentuk strategi pengurangan ketidakpastian yaitu strategi pengurangan ketidakpastian secara interaktif. Dengan berbicara secara langsung seseorang akan dengan mudah mengetahui bagaimana karakteristik lawan bicaranya, mereka akan mendapatkan gambaran yang sebenarnya dan pembuktian dari pengamatan dan pencarian informasi yang telah dilakukan sebelumnya. Karena sejatinya orang berkomunikasi untuk beradaptasi dengan lingkungannya (Suryanto, 2015).

Pemain dan pelatih melakukan komunikasi interpersonal diluar lapangan maupun di dalam lapangan. Pada saat dilapangan mereka membicarakan sesuatu tentang sepakbola, tentang strategi dan teknik, serta materi lain mengenai sepakbola. Sedangkan diluar lapangan mereka membahas apapun sampai masalah pribadi dan juga bercanda. Seperti yang dijelaskan di awal komunikasi yang baik akan membuat relasi yang baik pula. Kesinambungan dan relasi antar pemain dan pelatih akan terjalin dengan baik seiring dengan komunikasi yang baik pula antara keduanya.

\section{Output interaksi}

Seperti yang telah dijelaskan pada awal pembahasan bahwa komunikasi antarpribadi berhubungan dengan relasi, jika komunikasi yang terjalin berjalan baik maka akan semakin bagus juga relasi kedepannya (West \& Turner, 2012). Komunikasi yang baik juga akan merubah persepsi seseorang. Dalam hal ini persepsi awal pemain yang mengatakan bahwa pelatih galak, menakutkan, dan lain sebagainya patah karena pemain telah melakukan interaksi dengan pelatih secara langsung. Begitu juga dengan konsep diri pemain yang tidak merasa percaya diri akan lebih percaya diri lagi karena dia lebih mengenal tentang lingkungannya sehingga dia bisa dengan percaya diri melakukan atau menunjukkan kemapuannya tanpa rasa cemas dan malu malu.

Selain itu tujuan pemain dan pelatih untuk melaksanakan kegiatan belajar mengajar tentang sepakbola yang baik dapat terlaksana karena adanya pemahaman yang baik pula antara pemain dan pelatih. Dengan adanya relasi dan kedekatan antara pemain dan pelatih membuat tim sepakbola akan kompak dan mampu meraih tujuan utama mereka dengan mudah karena strategi yang mereka terapkan berhasil di dalam lapangan atau pada saat bermain. Pernyataan ini sesuai dengan definisi komunikasi yang mengatakan bahwa komunikasi merupakan proses penyampaian informasi, gagasan, emosi, keahlian, dan lain-lain melalui penggunaan simbol berupa kata, tanda, gambar, dan lain-lain (Suryanto, 2015). Komunikasi yang dilakukan pelatih dalam menyampaikan informasi berupa verbal maupun nonverbal dapat diterima dengan baik oleh pemain sehingga tercapai suatu tujuan dalam komunikasi tersebut.

\section{KESIMPULAN}

Berdasarkan data yang diperoleh oleh peneliti dan didukung oleh berbagai teori yang telah diuraikan, peneliti menarik kesimpulan bahwa ketidakpastian yang dialami oleh pemain dan pelatih Pasoepati Football Academy kelahiran 2004-2005 merupakan ketidakpastian kognitif dimana pemain dan pelatih tidak memiliki gambaran awal mengenai pemain atau pelatih itu sendiri sehingga mereka tidak tahu bagaiman haerus berperilaku dan bersikap. Ketidakpastian terbesar dialami pemain dimana pemain yang memiliki usia yang lebih muda dan belum banyak memiliki pengalaman dan juga rasa percaya diri yang tinggi akan lebih sulit untuk beradaptasi dengan lingkungan baru mereka, hal ini berpengaruh kepada persepsi dan konsep diri yang mereka bangun di awal masuk akademi sepakbola ini. Selain itu rasa ketergantungan pemain dengan orangtua juga menjadi faktor ketidakpastian yang dialami oleh pemain. Sedangkan pelatih hanya memiliki informasi secara mendasar saja mengenai pemain yang akan dilatihnya, padahal dalam sepakbola usia dini dibutuhkan pengertian dari pelatih yang lebih besar mengingat usia pemain yang masih muda.

Dengan adanya faktor penghambat tersebut membuat pemain dan pelatih berusaha untuk mengurangi ketidakpastian mereka. Seperti yang dikatankan Berger bahwa setiap orang yang mengalami ketidakpastian akan memiliki dorongan untuk menguranginya (Griffin, 2006). Mereka mengurangi ketidakpastian dengan harapan mampu memahami satu sama lain dan menjadikan mereka satu tim yang solid dan kompak. Strategi yang mereka gunakan dalam mengurangi ketidakpastian yang mereka hadapi sama dengan strategi yang dijelaskan oleh Charles Berger dalam mengurangi ketidakpastian.

Ada tiga strategi yang dilakukan dalam mengurangi ketidakpastian antara pemain dan pelatih Pasoepati Football Academy, pertama strategi aktif dilakukan pemain dengan cara mencari informasi mengenai Pasoepati Football Academy 
dan pelatih mereka melalui media sosial dan bertanya kepada rekan yang sudah masuk ke Pasoepati Football Academy terlebih dahulu, sedangkan strategi aktif yang dilakukan oleh pelatih yaitu mencari informasi dengan cara mengadakan pertemuan rutin dengan orangtua murid dan juga melakukan pengamatan saat seleksi awal masuk tim.

Kedua, strategi pasif dimana pemain dan pelatih sebelum melakukan interaksi satu sama lain sebelumnya mereka melakukan pengamatan terlebih dahulu secara pribadi dan langsung. Pemain mengamati bagaimana cara pelatih dalam melatih pada saat menangani tim lain, sedangkan pelatih melakukan pengamatan pada saat pemain melakukan latihan dan pada saat seleksi awal masuk pemain.

Ketiga, strategi interaktif dengan cara melakukan interaksi secara langsung. Setelah pemain dan pelatih mendapatkan gambaran mengenai satu sama lain strategi interaktif dilakukan untuk membuktikan gambaran-gambaran yang telah didapatkan sebelumnya. Interaksi yang dilakukan pemain dan pelatih dengan cara menyapa, berbincang, dan bercanda bersama merupakan strategi interaktif dalam mengurangi ketidakpastian.

\section{DAFTAR PUSTAKA}

Andrianto, J. R. (2013). Pengembangan Model latihan Teknik Dasar Ball Feeling Sebakbola Menggunakan Media Pembelajaran Audio Visual pada Siswa Usia 11 Tahun Sekolah Seoakbola Sanggar Kegiatan Belajar (SSB SKB) Gudo Kabupaten Jombang. Bravo's Jurnal VOL.02/NO.03.

Budyatna, M. (2015). Teori Teori Mengenai Komunikasi Antarpribadi. Jakarta: Prenadamedia Group.

Febriyani, N. W., \& Iqbal, F. (2015). Studi Fenomenologi pada Peserta On The Job Training Program ke Jepang dari PT. Hitachi Construction Machinery Indonesia Periode Pemberangkatan Tahun 1009-1012. Jurnal Komunikasi Profetik Vol.08/ No.02/Oktober2015.

Griffin, E. (2006). A First Look At Communication theory 6th edition. New York: McGraw-Hill.

Harapan, E., \& Ahmad, S. (2014). Komunikasi Antarpribadi Perilaku Insani Dalam organisasi Pendidikan. Jakarta: PT Raja Grafindo Persada.

Hardjana, A. M. (2003). Komunkasi Intrapersonal dan Komunikasi Interpersonal. Yogyakarta: Kanisius.

Hutagalung, I. (2015). Teori Teori Komunikasi Dalam pengaruh Psikologi. Jakarta Barat: Indeks.

Junaedi, F., \& Sukmono, F. G. (2018). Komunikasi Kesehatan: Sebuah Pengantar Komprehensif. Jakarta: Prenadamedia Group.

jung, j., Hoog, M. A., \& Choi, H. S. (2018). Recategorization and ingroup projection: Two processes of identity uncertainty reduction. Journal of Theoretical Social Phsychology DOI: 10.1002/jts5.37, 97-114.

Kriyantono, R. (2010). Teknik Praktis Riset Komunikasi. Jakarta: Kencana.

Littlejohn, S. W., \& Foss, K. A. (2009). Theories Of Human Communication. Jakarta: Salemba Humanika.

Morissan. (2018). Teori Komunikasi Individu Hingga Massa. Jakarta: Prenadamedia Group.

Peranginangin, B. B., \& Perbawaningsih, Y. (2016). MODEL KOMUNIKASI INTERPERSONALGENERASI MUDA SUKU BATAK KARO DI YOGYAKARTA MELALUI TRADISI ERTUTUR. Jurnal Komunikasi ASPIKOM, Volume 2 Nomor 6, Januari 2016, hlm 425-436.

Primasari, W. (2014). Pengelolaan Kecemasan dan Ketidakpastian Diri Dalam Berkomunikasi Studi Kasus Mahasiswa Perantau UNISMA Bekasi. Jurnal Komunikasi No.12 Vol 01, 26-38.

Prof. Dr. Muhammad Budyatna, M. (2015). Teori Teori mengenai Komunikasi Antarpribadi. Jakarta: Prenadamedia Group.

Sakti, D. B. (2018). Pola Komunikasi Kryawan Baru Terhadap Karyawan Lama (Studi Deskriptif Kualitatif di RS PKU Muhammadiyah Kartasura Dilihat dari Sudut Pandang Teori Pengurangan Ketidakpastian) .

Şengün, S. $\left.\left(Y_{\cdot}\right) \varepsilon\right)$. A Semiotic Reading of Digital Avatars and Their Role of Uncertainty Reduction in Digital Communication. Journal of Media Critiques ISSN: 2056-9793 University of Lincoln, United Kingdom.

Sudaryono, D. (2018). Metodologi Penelitian. Depok: PT Rajagrafindo Persada.

Suryanto. (2015). Pengantar Ilmu Komunikasi. Bandung: Pustaka Setia.

Trainers, E. F. (2017). Panuan Kepelatihan Sepakbola Anak Erlangga Football Trainers. Jakarta: Esensi.

West, R., \& Turner, L. H. (2012). Pengantar Teori Komunikasi Analisis dan Aplikasi edisi 3. Jakarta: Salemba Humanika 
